\title{
Forage cactus associated with different fiber sources for lactating Sindhi cows: production and composition of milk and ingestive behavior
}

\author{
Carla Aparecida Soares Saraiva1, Severino Gonzaga Neto', Lara Toledo Henriques' ${ }^{1}$, Maria \\ Fernanda Soares Queiroz ${ }^{2}$, Edilson Paes Saraiva', Rômulo Pontes de Freitas Albuquerque ${ }^{3}$, \\ Vinicius de França Carvalho Fonseca ${ }^{4}$, George Vieira do Nascimento ${ }^{5}$
}

\footnotetext{
${ }^{1}$ Universidade Federal da Paraiba, Centro de Ciências Agrárias, Areia, PB, Brasil.

2 Universidade Federal da Paraíba, Centro de Ciências Humanas, Sociais e Agrárias, Bananeiras, PB, Brasil.

${ }^{3}$ Empresa Estadual de Pesquisa Agropecuária da Paraíba S. A., Alagoinha, PB, Brasil.

${ }^{4}$ Universidade Federal da Paraíba, Programa de Doutorado Integrado em Zootecnia, Areia, PB, Brasil.

${ }^{5}$ Universidade Federal de Campina Grande, Programa de Pós-graduação em Sistemas Agrosilvipastoris, Patos, PB, Brasil.
}

\begin{abstract}
The objective of this study was to evaluate the association of forage cactus with different fiber sources (elephant grass hay - EGH; corn straw - CS, hay of cassava shoots - HCS; fresh sugarcane bagasse - FSB; and hydrolyzed sugarcane bagasse - HSB) on the milk yield and composition and the feeding behavior of lactating Sindhi cows. Five cows with average body weight, average daily milk yield, and average daily 4\%-fat-corrected milk yield of 265, 4.95 and $5.22 \mathrm{~kg}$, respectively, were used in a $5 \times 5$ Latin square design. The effect of experimental diets on milk yield and composition, feeding time (FT), rumination time (RT), idle time, mean values of total chewing time (TCT), number of ruminal boli (NRB), number of rumination chews (NRC), and feed efficiency (FE) and rumination efficiency (RE) expressed as a function of DM and NDF were analyzed. Milk yield in kg/day and corrected to $4.0 \%$ fat from the animals that received cactus associated with CS were higher as compared with the treatment with hydrolyzed sugarcane bagasse. The milk composition variables were not influenced by the treatments, and nor were FT, RT, TCT, NRB and NC. Two patterns were observed for FE and RE, with higher efficiency of the diets with EGH, CS and HCS and lower efficiency for diets containing sugarcane bagasse. In this context, Sindhi cows fed forage cactus associated with corn straw, elephant grass hay, and hay of cassava shoots present better performance, feeding efficiency, and rumination responses than those fed forage cactus associated with fresh sugarcane bagasse and hydrolyzed sugarcane bagasse.
\end{abstract}

Key Words: feeding behavior, milk composition, milk production, roughage, Zebu

\section{Introduction}

In the Northeast, milk production has been based on the use of native and cultivated pastures, with important participation of forage cactus (Opuntia ficus-indica Mill. Nopalea cochenillifera Salm. Dyck.), especially in the driest period of the year (Moreira et al., 2006).

One of the main attributes of forage cactus is its high content of water, and it can be very beneficial in droughtprone areas. However, the forage has a low content of crude protein (CP), neutral detergent fiber (NDF) and acid detergent fiber (ADF) and a high content of non-fiber carbohydrates (NFC). According to Ferreira (2005), this aspect should be taken into account when forage is used in ruminant feeding; its indiscriminate use has caused several problems, such as diarrhea, drop in milk-fat, low dry matter intake and weight loss.

Received October 31, 2013 and accepted October 1, 2014

Corresponding author: carla@cca.ufpb.br

http://dx.doi.org/10.1590/S1806-92902015000200004

Copyright (@) 2015 Sociedade Brasileira de Zootecnia. This is an Open Access article distributed under the terms of the Creative Commons Attribution Non-Commercial License, which permits unrestricted non-commercial use, distribution, and reproduction in any medium, provided the original work is properly cited.
Several studies have shown the positive effects of spineless cactus associated with fibrous feed, e.g., absence of diarrhea, maintenance of normal patterns of milk fat, in addition to ensuring good milk production by animals (Mattos et al., 2000; Silva et al., 2007; Cavalcanti et al., 2008). This positive association is related to the requirements of NDF by ruminants. The NRC (2001) recommends that the diet of dairy cows contain at least $250 \mathrm{~g} / \mathrm{kg}$ of NDF in the DM and $190 \mathrm{~g} / \mathrm{kg}$ of the forage NDF is derived.

The inclusion of fiber feeds in forage diets can prevent digestive disorders by increasing microbial activity in the rumen (Ben Salem et al., 1996). This fact is related to the requirements of NDF in ruminant animals, specifically physically effective fiber. Due to the need for associating this feed with a fibrous source, feeds such as elephant grass hay, corn straw, sugarcane bagasse and hay of cassava shoots are relevant alternatives, since they are present in northeastern Brazil. The adoption of low-cost diets, based mostly on forage and byproducts, is justified mainly for feeding more rustic animals.

The Sindi breed are zebu animals, which, because of hardiness and heat tolerance, spread through Asia, Oceania, 
Africa and the Americas. Since its introduction in in Brazilian territory, Sindhi cattle have remained concentrated in a few herds, not presenting the numerical evolution observed in other breeds, concentrating mainly in the Northeast.

Therefore, this study aimed at evaluating the effect of different fiber sources associated with forage cactus on the productive performance of lactating Sindi cows and feeding behavior.

\section{Material and Methods}

The experiment was conducted in the municipality of Alagoinha, Paraíba State, Brazil.

The treatments consisted of forage cactus (Nopalea cochenillifera Salm-Dyck) associated with different fiber sources (Tables 1 and 2).

Five cows of Sindhi breed, $265 \mathrm{~kg}$ mean live weight, first order of delivery, between 60 and 90 days of lactation, with production at the beginning of the experiment of $2.5 \mathrm{~kg}$ of milk per day, were housed in individual stalls provided with individual troughs and drinkers for feed-intake control. The experimental design was a Latin square with five cows, five periods and five treatments. Each period lasted 15 days during which 10 days were for adaptation of animals to diets and five for collecting data and samples, totaling 75 days of experimental period.

The experimental diets were formulated according to the NRC (2001) to meet the requirements of animals of low-yield potential, average $6 \mathrm{~kg}$ milk/day, containing around $10.3 \% \mathrm{CP}$ in their formulation. The feed was given to the animals twice daily $(6.00 \mathrm{~h}$ and $15.00 \mathrm{~h})$ as a complete diet, allowing leftovers of 10 to $20 \%$ of total dry matter provided as a means to maintain the levels of ingredients in the diets.

The forage used in the experiment was Nopalea cochenillifera (L) cv. Miúda, acquired in the region of Alagoinha-PB. Hays of elephant grass and cassava shoots were made with the material available on site. The corn straw was purchased from producers in the region, consisting of the resulting material from stem removal for human consumption. The sugarcane bagasse was periodically obtained from private mills and stored in a covered area, used fresh and also hydrolyzed by a chemical process. The treatment of hydrolyzed sugarcane bagasse consisted of adding $3 \mathrm{~kg}$ of hydrated lime dissolved in $50 \mathrm{~L}$ of water $/ 100 \mathrm{~kg}$ of bagasse (Mattos et al., 2000).

The forage was previously processed in a forage machine and weighted for animal feeding. The remaining ingredients was also weighed individually, then placed in troughs, mixed and supplied to the animals.

Milking was performed once a day, at $05.00 \mathrm{~h}$, and during the period of experimental data collection calves remained for four hours with the cow after milking and after this period they were separated from their mothers and taken to a paddock where they remained until the following day. The cows were milked only at $17.00 \mathrm{~h}$ to total udder exhaustion, with the production of the next day multiplied by two, since cows had been milked 12 hours before.

Table 1 - Proportions of ingredients in the diet

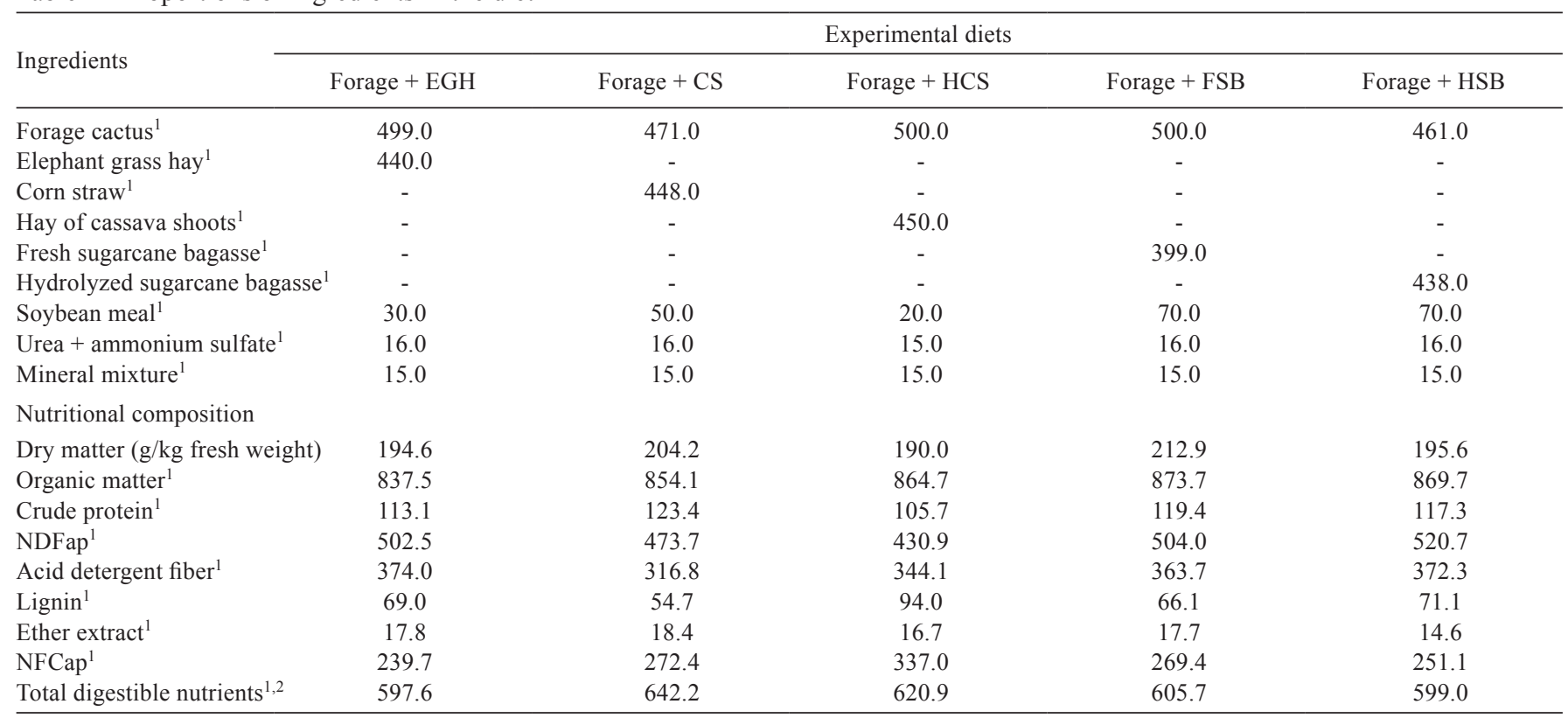

EGH - elephant grass hay; CS - corn straw; HCS - hay of cassava shoots; FSB - fresh sugarcane bagasse; HSB - hydrolyzed sugarcane bagasse.

NDFap - neutral detergent fiber corrected for ash and protein; NFCap - non-fibrous carbohydrates corrected for ash and protein.

${ }^{1} \mathrm{In} \mathrm{g} / \mathrm{kg}$ DM.

${ }^{2}$ Patterson et al. (2000). 
Table 2 - Composition of the ingredients of experimental diets

\begin{tabular}{lccccccc}
\hline & Forage & EGH & CS & HCS & FSB & HSB & $\begin{array}{c}\text { Soybean } \\
\text { meal }\end{array}$ \\
\hline $\mathrm{DM}$ & 110.8 & 848.0 & 826.3 & 835.1 & 709.6 & 526.3 & 865.0 \\
$\mathrm{OM}^{1}$ & 843.9 & 882.1 & 914.1 & 942.0 & 966.9 & 946.7 & 943.0 \\
$\mathrm{MM}^{1}$ & 156.1 & 111.9 & 86.0 & 58.0 & 33.1 & 53.3 & 56.9 \\
$\mathrm{CP}^{1}$ & 58.3 & 51.6 & 53.1 & 52.2 & 18.5 & 17.3 & 539.2 \\
$\mathrm{EE}^{1}$ & 18.9 & 17.3 & 18.4 & 14.9 & 16.2 & 09.3 & 25.3 \\
$\mathrm{NDFap}^{1}$ & 315.0 & 774.7 & 709.7 & 601.0 & 833.0 & 833.4 & 148.7 \\
$\mathrm{ADF}^{1}$ & 249.7 & 559.4 & 432.4 & 482.4 & 579.3 & 569.6 & 109.9 \\
NFCap $^{1}$ & 427.5 & 44.3 & 132.8 & 273.8 & 99.2 & 86.6 & 229.9 \\
Lignin $^{1}$ & 34.0 & 117.2 & 84.5 & 170.4 & 120.4 & 124.0 & 15.2 \\
\hline
\end{tabular}

EGH - elephant grass hay; CS - corn straw; HCS - hay of cassava shoots; FSB - fresh sugarcane bagasse; HSB - hydrolyzed sugarcane bagasse.

DM - dry matter; OM - organic matter; MM - mineral matter; CP - crude protein; EE - ether extract; NDFap - neutral detergent fiber corrected for ash and protein; ADF - acid detergent fiber; NFCap - non-fiber carbohydrates corrected for ash and protein.

${ }^{1}$ In $\mathrm{g} / \mathrm{kg} \mathrm{DM}$

In the five periods of data collection, milk samples were collected from each animal, always on the 14th day of each experimental period: an aliquot of $500 \mathrm{~mL} / \mathrm{milking} /$ cow. Samples were stored in polyethylene containers and physicochemical determinations were performed. The fat content, protein, lactose, density and solids nonfat were determined. The milk was corrected for $4.0 \%$ fat according to the equation: fat-corrected milk $(\mathrm{FCM})=0.4 \times(\mathrm{kg}$ of milk $)+15 \times(\mathrm{kg} \mathrm{milk} \times \%$ fat $) / 100(\mathrm{NRC}, 1989)$.

The feeding behavior of the animals was observed on the 14th day of each experimental period for $24 \mathrm{~h}$, with the following events being observed every 5 min: eating, ruminating and idling. The total time spent on each activity was calculated by multiplying the total number of observations by five, according to the methodology described by Bürger et al. (2000). During nocturnal observation, the environment was maintained with artificial lighting.

The number of chews per ruminal bolus and time spent in chewing by ruminal bolus were determined on the 15th day of each experimental period, registering three values distributed in hours from 10.00 to $12.00 \mathrm{~h}, 14.00$ to 16.00 $\mathrm{h}$, and 18.00 to $20.00 \mathrm{~h}$, using a digital stopwatch.

The feeding efficiency (FE), rumination efficiency (RE) and total chewing time (TCT, h/day), as the sum of the time eating and ruminating $(\mathrm{FT}+\mathrm{RT})$, were determined according to Burger et al. (2000). The results for factors of feeding behavior were obtained using the following equations:

$$
\begin{gathered}
\mathrm{NRB}=\mathrm{RT} / \mathrm{NC} ; \\
\mathrm{NC}=\mathrm{NRB} \times \mathrm{NC} ; \\
\mathrm{FE}_{\mathrm{DM}}=\mathrm{DMI} / \mathrm{FT} ; \mathrm{FE}_{\mathrm{NDF}}=\mathrm{NDFI} / \mathrm{FT} ; \\
\mathrm{RE}_{\mathrm{DM}}=\mathrm{DMI} / \mathrm{RT} ; \mathrm{RE} \mathrm{NDF}_{\mathrm{NDF}}=\mathrm{NDF} / \mathrm{RT} ; \text { and } \\
\mathrm{TCT}=\mathrm{FT}+\mathrm{RT},
\end{gathered}
$$

in which: $\mathrm{NRB}=$ number of ruminal boli; $\mathrm{NC}=$ daily number of chews; $\mathrm{FE}_{\mathrm{DM}}=$ feed efficiency of DM ( $\mathrm{g}$ DM consumed $/ \mathrm{h}) ; \mathrm{FE}_{\mathrm{NDF}}=$ feed efficiency of $\mathrm{NDF}(\mathrm{g} \mathrm{NDF}$ consumed/h); DMI (g) = daily dry matter intake; NDFI $(\mathrm{g})=$ daily neutral detergent fiber intake; FT = time spent feeding daily; $\mathrm{RE}_{\mathrm{DM}}=$ rumination efficiency of $\mathrm{DM}$ ( $\mathrm{g}$ of ruminated $\mathrm{DM} / \mathrm{h}$ ); $\mathrm{RE}_{\mathrm{NDF}}=$ rumination efficiency of $\mathrm{NDF}$ $(\mathrm{g}$ ruminated $\mathrm{NDF} / \mathrm{h}) ; \mathrm{RT}(\mathrm{h} /$ day $)=$ rumination time; and $\mathrm{TCT}=$ total chewing time ( $\mathrm{h} /$ day).

The analysis of variance was performed with the $\mathrm{SAS}^{\circledR}$ (Statistical Analysis System, version 8.2 for Windows ${ }^{\circledR}$ ) statistical software, and the means of milk yield, milk constituents, and feeding behavior were compared by the Tukey test at $5 \%$ probability.

\section{Results}

There was no effect $(\mathrm{P}>0.05)$ of the different treatments in this experiment on the content of milk fat, protein, lactose, density and solids nonfat (Table 4). However, animals that received forage associated with corn straw had higher $(\mathrm{P}<0.05)$ milk yield and $4.0 \%$-fat-corrected milk yield as compared with the treatment with hydrolyzed sugarcane bagasse; however, the yield was not significantly different $(\mathrm{P}>0.05)$ from the animals fed forage diets associated with EGH, HCS or FSB.

The CP content and its intake by animals (Tables 2 and 3 ) revealed a potential for higher milk production by animals fed forage associated with CS, EGH and HCS compared with the diets containing bagasse. According to the recommendations of the NRC (1989), $90 \mathrm{~g} \mathrm{CP}$ are needed per $\mathrm{kg}$ of milk produced and $3.5 \mathrm{~g} \mathrm{CP} / \mathrm{LW}^{0.75}$ for maintenance requirement; in this case the animals in this experiment would have the potential to produce 8.33, $10.22,7.33,5.56$ and $4.78 \mathrm{~kg}$ milk/day for the diets with forage associated with EGH, CS, HCS, FSB and HSB, respectively. However, considering the TDN requirements, which are $322 \mathrm{~g}$ TDN for each $\mathrm{kg}$ of milk and $35 \mathrm{~g}$ TDN/LW ${ }^{0.75}$ for maintenance requirements, milk yield would be only $5.62,5.60,5.90,4.38$ and $2.21 \mathrm{~kg}$ milk/day for diets with forage associated with EGH, CS, HCS, FSB and HSB, respectively. Therefore, the TDN intake was a limiting factor in milk production of animals. Thus, it is evident that the recommendations of the NRC (1989) to meet the CP and NDF requirements for milk production of dual-capability Zebu animals do not meet or predict the performance of those animals.

The animals had a mean fat content of $43.2 \mathrm{~g} / \mathrm{kg}$, above the 35.0 to $38.0 \mathrm{~g} / \mathrm{kg}$ commonly reported for Holstein cows, which agrees with the results reported by Galvão 
Júnior et al. (2010), who found $44.8 \mathrm{~g} / \mathrm{kg}$ for fat of Zebu cows producing up to $10 \mathrm{~kg}$ milk/day. Although animals evaluated in this study are low production, the contents of milk protein and lactose were also high, due to the higher concentration of these nutrients.

When the feeding behavior of animals in this experiment was evaluated, no significant differences $(\mathrm{P}>0.05)$ were detected for the mean time spent on feeding, rumination and idling, total chewing time (TCT), number of ruminal bolus (NRB) and number of chews a day (NC), with mean values of 5.54, 8.30 and $13.85 \mathrm{~h}$ /day and 216.47 and 10,990.49/ day, respectively (Table 5).
Animals fed forage associated with HCS had higher $(\mathrm{P}<0.05)$ feed efficiency (FE) expressed in $\mathrm{gDM} / \mathrm{h}$, followed by the diets containing forage with EGH and with CS, which showed no significant difference between them, and, lastly, with the worst FE, the diets with forage associated with FSB and HSB, which were also statistically equal to each other $(\mathrm{P}>0.05)$.

For FE expressed in $\mathrm{gNDF} / \mathrm{h}$ and RE expressed in $\mathrm{gDM} / \mathrm{h}$, diets with forage associated with EGH, CS and HCS were significantly higher $(\mathrm{P}<0.05)$ compared with diets with sugarcane bagasse. For RE expressed in $\mathrm{gNDF} / \mathrm{h}$, the diets with EGH and CS were significantly higher $(\mathrm{P}<0.05)$ than

Table 3 - Average intakes and apparent digestibility of nutritional components in Sindhi cows fed diets with forage cactus associated with different fiber sources

\begin{tabular}{|c|c|c|c|c|c|}
\hline \multirow{2}{*}{ Ingredients } & \multicolumn{5}{|c|}{ Experimental diets } \\
\hline & Forage + EGH & Forage $+\mathrm{CS}$ & Forage $+\mathrm{HCS}$ & Forage + FSB & Forage + HSB \\
\hline \multicolumn{6}{|l|}{ Intake } \\
\hline $\mathrm{CP}$ (kg/day) & 0.98 & 1.15 & 0.89 & 0.73 & 0.66 \\
\hline NDF (kg/day) & 4.21 & 4.20 & 3.44 & 3.01 & 2.67 \\
\hline NDF $(\% \mathrm{LW})$ & 1.62 & 1.59 & 1.30 & 1.14 & 1.01 \\
\hline $\mathrm{DM}$ & 52.00 & 50.12 & 53.07 & 63.99 & 58.45 \\
\hline $\mathrm{CP}$ & 70.06 & 65.34 & 61.99 & 79.15 & 74.78 \\
\hline $\mathrm{NDF}$ & 38.00 & 36.20 & 27.29 & 48.96 & 44.86 \\
\hline
\end{tabular}

DM - dry matter; CP - crude protein; NDFap - neutral detergent fiber; TDN - total digestible nutrients.

Table 4 - Milk yield, milk composition and coefficient of variation (CV) of Sindhi breed cows fed diets with forage cactus associated with different fiber sources

\begin{tabular}{|c|c|c|c|c|c|c|}
\hline & & & xperimental die & & & \\
\hline & Forage + EGH & Forage $+\mathrm{CS}$ & Forage $+\mathrm{HCS}$ & Forage + FSB & Forage + HSB & $\cos (10)$ \\
\hline Milk yield (kg/day) & $5.24 \mathrm{ab}$ & $6.09 \mathrm{a}$ & $4.76 \mathrm{ab}$ & $4.62 \mathrm{ab}$ & $4.04 b$ & 16.18 \\
\hline FCM (kg/day) & $5.94 \mathrm{ab}$ & $6.23 a$ & $5.00 \mathrm{ab}$ & $4.72 \mathrm{ab}$ & $4.24 b$ & 18.25 \\
\hline Fat $(\mathrm{g} / \mathrm{kg})$ & 48.0 & 41.4 & 43.1 & 41.9 & 41.7 & 14.80 \\
\hline Protein $(\mathrm{g} / \mathrm{kg})$ & 43.7 & 42.5 & 44.4 & 43.7 & 43.0 & 5.68 \\
\hline Lactose $(\mathrm{g} / \mathrm{kg})$ & 36.8 & 35.0 & 37.9 & 36.8 & 35.7 & 10.03 \\
\hline Density (g/L) & 1.026 & 1.025 & 1.027 & 1.026 & 1.026 & 9.57 \\
\hline Solids nonfat $(\mathrm{g} / \mathrm{kg})$ & 87.0 & 83.8 & 89.0 & 87.0 & 85.0 & 7.72 \\
\hline
\end{tabular}

Means in the row followed by different letters are different by the Tukey test $(\mathrm{P}<0.05)$.

FCM - 4.0\%-fat-corrected milk.

Table 5 - Ingestive-behavior variables and coefficient of variation (CV) according to the the experimental diets

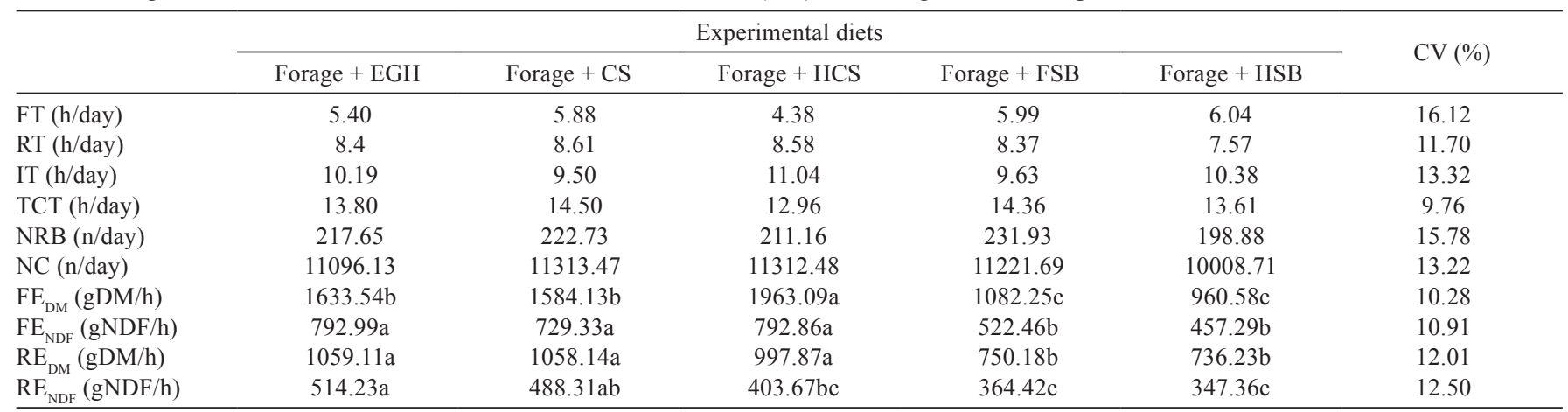

FT - feeding time; RT - rumination time; IT - idle time; TCT - total chewing time; NRB - number of ruminal boli; NC - number of chews; FE - feeding efficiency; RU - rumination efficiency. 
those with FSB and HSB. The RE for the HCS diet was lower $(\mathrm{P}<0.05)$ compared with that of $\mathrm{EGH}$.

An important fact to be noted in this study are the values of $\mathrm{NRB}, \mathrm{NC}$, and $\mathrm{FE}$ and $\mathrm{RE}$ (expressed in $\mathrm{gDM} / \mathrm{h}$ and $\mathrm{gNDF} / \mathrm{h}$ ), which were quite lower than those found in the literature for cows, but feeding, rumination and idling time were similar between them.

\section{Discussion}

The results for the milk yield found here probably reflect the higher DM, CP and TDN intake (Table 3) in the treatment with CS compared with the diet with HSB, since there was a certain rejection by animals to diets with sugarcane bagasse during the experiment, and preference for the other diets evaluated. One of the factors that may have affected the intake was the high lignin content of sugarcane bagasse (Table 2), which causes a lower passage rate in the rumen-reticulum and consequently the reduction in intake. It was also observed that the experimental animals selected forage cactus over the bagasse in diets that contained bagasse in their composition, even though the sugarcane bagasse had been processed in a forage shredder to reduce the particle size.

Besides TDN, another factor to be stressed is the fact that they are cows at first calving with a live weight of $265 \mathrm{~kg}$, which also reserve part of nutrients for growth, beyond the limitations imposed by the genetic potential of the animal. It is known that Zebu animals have higher genetic potential for meat production at the expense of milk production. Although the Sindhi breed is considered dual-capability, the low milk yield commonly reported in the literature indicates a low potential for milk production, or at least the need for greater investment in genetic breeding, with a view to selecting dams and sires with greater potential for milk production.

Moura et al. (2009), using data from a farm located in the microregion of Cariri Ocidental of Paraíba State, found a mean milk yield of $6.78 \mathrm{~kg}$ per day for Sindhi cows. Therefore, considering the results of this study and other studies in the literature, there is a lower milk yield in this breed compared with other dairy Zebu breeds such as dairy Gir.

Considering the breed factor, Zebu animals usually have higher fat content in milk compared with animals of mainly dairy breeds, and it is known that other factors such as lactation, season of birth, birth order, milk yield, nutrition, health, breed, animal age, among others, are also influential, which is evidenced in this study.

In the evaluation of diets rich in fiber, characteristics inherent to the animal such as feeding behavior are of great value. According to Mendonça et al. (2004), the study of feeding behavior is an important tool in assessing diets, enabling the adjustment of the feeding regime of animals to obtain better production.

Although feeds with high NDF need more time to be chewed and consequently ruminated to reduce the particle size and promote better attack of ruminal microorganisms on the food, there was no increased rumination in this study that extrapolated 8 to $9 \mathrm{~h}$ daily. These results observed for ruminating time are consistent with Welch (1982), who states that increased supply of low-digestibility fiber does not increase rumination by more than 8 to $9 \mathrm{~h}$ /day.

By the NDF intake and digestibility of bagasse diets (Table 3), it is possible that the animals selected greater amounts of forage cactus in the diet and, therefore, there was lower NDF intake in both FSB and HSB. Therefore, although animals receiving diets with sugarcane bagasse showed lower NDF intake, it was not enough to change the feeding time compared with the others, possibly due to the longer time spent at the trough by animals to select their favorite dietary ingredient, i.e., forage cactus. The rumination time was not different $(\mathrm{P}>0.05)$ between diets due to the lower digestibility of the fiber fraction in diets with sugarcane bagasse, because although they select forage in these diets, there was ingestion of bagasse, thus compensating the lower NDF intake. Higher NDF intakes are usually associated with increased rumination time; however, according to Nocek (1997), though NDF can predict nutrient intake and feeding behavior, other factors must be considered, such as degree of NDF indigestibility, content of potentially degradable fiber and rate of fiber degradation in the rumen.

Similar to that observed in milk yield, greater efficiencies (FE and RE) were observed for diets with EGH, $\mathrm{CS}$ and HCS and lower efficiencies for diets containing bagasse. This is probably a result of the DM and nutrients intake (Table 3).

Ramos et al. (2007), working on dairy cows fed diets associated with different forages, found that FE and RE, depending on the DM intake, did not differ between diets, and according to the authors this occurred because there was no difference between the times spent for eating and rumination and ingestion of dry matter. In this study, although there was no difference for feeding among diets, lower absolute values were observed for feeding time with the HCS diet, and because it presented one of the highest IDM (Table 3), the higher FE expressed in $\mathrm{gDM} / \mathrm{h}$ is explained.

Sousa et al. (2009), comparing diets based on corn silage and sugarcane for dairy cows, observed higher DM and NDF in the diet with corn silage compared with 
sugarcane, but similar times for feeding and rumination, thus allowing higher FE and RE for both DM and for NDF in diets with corn silage. A similar phenomenon occurred in this study for diets based on EGH, CS and HCS compared with diets with sugarcane bagasse.

The diet with forage associated with HCS had one of the lowest NDF; however, it presented a similar NDF intake to other diets, besides low digestibility for this component (Table 3). Thus, lower FE and RE were expected, especially when expressed in $\mathrm{gNDF} / \mathrm{h}$. A fact that may have influenced it was the small particle size of HCS, which provided better adherence to forage due to exposure of its mucilage when processed in a forage machine. In this context, the high forage palatability associated with these factors enabled a high intake of DM and consequently of the NDF fraction.

The lower rumination efficiency of diets with FSH and HSB can be explained by the lower DM intake due to greater rejection of these diets, which made the animals choose forage cactus and consequently also led to a lower intake of NDF. According to Van Soest (1994), concentrate feed and finely ground or pelleted hay reduce rumination time, while roughages with a high cell-wall content tend to increase the rumination time, and the increased intake also tends to reduce the rumination time per gram of food.

Ruminants need roughage in their diet to maximize production and maintain health through the support of a stable environment in the rumen. The ability of forage to stimulate chewing has been studied extensively because of the relationship between chewing and buffering saliva flow within the rumen, which is necessary to neutralize the acid production resulting from fermentation (Allen, 1997).

Ramos et al. (2007), working on forage cactus associated with different roughages such as sugarcane bagasse, Tifton hay, elephant grass hay, sorghum silage and sorghum silage associated with sugarcane bagasse, found FE and RE of $3380,2920,3070,3440,3200$, and 2150, 2030, 2080, 2240 and 2120 , both expressed in $\mathrm{g} D \mathrm{DM} / \mathrm{h}$, respectively.

Lima (2008) evaluated the feeding behavior of Sindhi and Guzerat cows fed sugarcane and urea in place of elephant grass and observed FE and RE expressed in $\mathrm{gDM} / \mathrm{h}$ of $1,660.97$ and 1,003.83, 1,087.60 and 742.38, and RE values expressed in $\mathrm{gNDF} / \mathrm{h}$ of 723.50 and 494.60 , respectively. As the analyzed variables depend on the DM and NDF intakes, with intake being defined based on the live weight of the animals, these results were expected. Zebu cows such as Sindhi are much smaller-sized as compared with Holstein cows; therefore, it is justifiable to have lower absolute values of FE and RE. In addition to the live weight of animals having been partly responsible for their lower FE and RE, the high NDF content in diets also influenced the results due to its effect on DM intake, since the forage NDF content is the feed component most associated with feed intake (Van Soest, 1994). In this case, the longer the time spent ruminating the shorter will be the time left to feeding itself, since rumination and feeding are competing events.

According to Dulphy et al. (1980), cited by Mendonça et al. (2004), the efficiency of rumination and chewing, expressed in $\mathrm{g} / \mathrm{h}$, can be reduced in high-fiber diets due to the greater difficulty in reducing the particle size of the fibrous materials.

\section{Conclusions}

Forage cactus may be associated with elephant grass hay, corn straw and hay of cassava shoots in diets for lactating Sindhi cows without impairing milk yield and causing changes in feeding behavior. Diets with forage cactus associated with fresh or hydrolyzed sugarcane bagasse are not well-accepted by the animals and reduce milk yield.

\section{Acknowledgments}

The authors thank Empresa Estadual de Pesquisa Agropecuária da Paraíba - EMEPA for providing the facilities and animals for the conduction of this experiment.

\section{References}

Allen, M. S. 1997. Relationship between fermentation acid production in the rumen and requirement for physically effective fiber. In: Symposium: meeting the fiber requirements of dairy cows. Journal of Dairy Science 80:1447-1462.

Ben Salem, H.; Nefzaoui, A.; Abdouli, H. and Ørskov, E. R. 1996. Effect of increasing level of spineless cactus (Opuntia ficus indica var. inermis) on intake and digestion by sheep given straw-based diets. Animal Science 62:293-299.

Bürger, P. J.; Pereira, J. C.; Queiroz, A. C.; Silva, J. F. C.; Valadares Filho, S. C.; Cecon, P. R. and Casali, A. D. P. 2000. Comportamento ingestivo em bezerros holandeses alimentados com dietas contendo diferentes níveis de concentrado. Revista Brasileira de Zootecnia 29:236-242.

Cavalcanti, C. V. A.; Ferreira, M. A.; Carvalho, M. C.; Véras, A. S. C.; Silva, F. M. and Lima, L. E. 2008. Palma forrageira enriquecida com uréia em substituição ao feno de capim tifton 85 em rações para vacas da raça Holandesa em lactação. Revista Brasileira de Zootecnia 37:689-693.

Ferreira, M. A. 2005. Palma forrageira na alimentação de bovinos leiteiros. UFRPE, Recife.

Galvão Júnior, J. G. B.; Rangel, A. H. N.; Medeiros, H. R.; Silva, J. B. A.; Aguiar, E. M.; Madruga, R. C. and Lima Júnior, D. M. 2010. 
Efeito da produção diária e da ordem de parto na Composição físico-química do leite de vacas de raças Zebuínas. Acta Veterinaria Brasilica 4:25-30.

Lima, F. H. S. 2008. Inclusão de cana-de-açúcar e uréia em rações para vacas Guzerá e Sindi em lactação. Dissertação (M.Sc.). Universidade Federal da Paraíba, Areia.

Mattos, L. M. E.; Ferreira, M. A.; Santos, D. C.; Lira, M. A.; Santos, M. V. F.; Batista, A. M. V. and Véras, A. S. C. 2000. Associação da palma forrageira (Opuntia ficus indica Mill) com diferentes fontes de fibra na alimentação de vacas 5/8 Holandês-Zebu em lactação. Revista Brasileira de Zootecnia 29:2128-2134.

Mendonça, S. S.; Campos, J. M. S.; Valadares Filho, S. C.; Valadares, R. F. D.; Soares, C. A.; Lana, R. P.; Queiroz, A. C.; Assis, A. J. and Pereira, M. L. A. 2004. Comportamento ingestivo de vacas leiteiras alimentadas com dietas à base de cana-de açúcar ou silagem de milho. Revista Brasileira de Zootecnia 33:723-728.

Moreira, J. N.; Araújo, G. G. L. and França, C. A. 2006. Potencial de produção de leite em pastagens nativas e cultivadas no semi-árido. p.61-79. In: Anais do 10ํㅗㅇósio Nordestino de Alimentação de Ruminantes. Embrapa Semi-Árido, Petrolina.

Moura, J. F. P.; Pimenta Filho, E. C.; Gonzaga Neto, S. and Pereira, W. E. 2009. Desempenhos produtivo e reprodutivo de vacas das raças Guzerá e Sindi, criadas no Semiárido Paraibano. Revista Científica de Produção Animal 11:72-85.

Nocek, J. E. 1997. In situ e outros métodos para estimar a proteína ruminal e a digestibilidade da energia. p.241-287. In: Anais do Simpósio Internacional de Digestibilidade em Ruminantes. UFLA FAEPE, Lavras.
NRC - Nutrient Research Council. 1989. Requeriments of the dairy cattle. 6th rev. ed. Washington, DC.

NRC - National Research Council. 2001. Nutrient requeriments of dairy cattle. National Academy Press, Washington, D.C.

Patterson, T.; Klopfenstein, T. J.; Milton, T. and Brink, D. R. 2000. Evaluation of the 1996 beef cattle NRC model predictions of intake and gain for calves fed low or medium energy density diets. Nebraska Beef Cattle Reports, Paper 385.

Ramos, A. O.; Veras, A. S. C.; Ferreira, M. A.; Azevedo, M.; Silva, R. R. and Fotius, A. C. A. 2007. Associação da palma forrageira com diferentes tipos de volumosos em dietas para vacas em lactação: comportamento ingestivo e parâmetros fisiológicos. Acta Scientarium Animal Science 29:217-225.

Silva, R. R.; Ferreira, M. A.; Véras, A. S. C.; Ramos, A. O.; Melo, A. A. S. and Guimarães, A. V. 2007. Palma forrageira (Opuntia ficus indica Mill) associada a diferentes volumosos em dietas para vacas da raça Holandesa em lactação. Acta Scientarium Animal Science 29:317-324.

Sousa, D. P.; Campos, J. M. S.; Valadares Filho, S. C.; Lana, R. P.; Sediyama, C. A. Z. and Mendes Neto, J. 2009. Comportamento ingestivo, consumo e digestibilidade de nutrientes, produção e composição do leite de vacas alimentadas com silagem de milho ou cana-de-açúcar com caroço de algodão. Revista Brasileira de Zootecnia 38:2053-2062.

Van Soest, P. J. 1994. Nutritional ecology of the ruminant. 2nd ed. Cornell University Press, Ithaca.

Welch, J. G. 1982. Rumination, particle size and passage from the rumen. Journal of Animal Science 54:885-894. 